\title{
磁场-渗流场耦合作用下的铁磁流体多孔介质流动 数值模拟
}

姚军 ${ }^{1 *}$, 黄涛 ${ }^{1}$, 黄朝琴 ${ }^{2 *}$, 谢昊君 ${ }^{1}$, 刘均荣 ${ }^{1}$, 张建光 ${ }^{1}$

1. 中国石油大学(华东)石油工程学院, 青岛 266580;

2. Department of Petroleum Engineering, Colorado School of Mines, Golden CO 80401, USA

* 联系人, E-mail: yaojun@upc.edu.cn; emc.group.upc@gmail.com

2016-10-31 收稿, 2016-12-18 修回, 2016-12-19 接受, 2017-02-17 网络版发表

国家自然科学基金(51234007，51490654，51404292，41502131)、山东省自然科学基金(ZR2014EEQ010)和中央高校基本科研业务费专项 (16CX06026A, 15CX05037A, 14CX05027A)资助

摘要铁磁流体作为一种新型功能材料, 由于同时具备磁性及流体性质被广泛应用于各个技术领域. 本文从数 值模拟理论上研究了利用磁场控制的铁磁流体驱油问题：针对外磁场作用下的铁磁流体多孔介质流动物理过程, 将磁力项引入铁磁流体相运动方程从而耦合磁场-渗流场给出其流动方程, 并采用全隐式有限体积法形成相应数 值离散格式; 通过二维均质填砂平板流动实验验证了模型和算法的正确性，在此基础上，对比了平面及纵向非均 质多孔介质中注水及注铁磁流体的驱油效果, 计算结果表明通过控制铁磁流体的驱替路径可以提高驱替波及范围 继而提高采收率, 为提高原油采收率提供了新的思路和方法.

关键词铁磁流体, 多孔介质, 磁场-渗流耦合, 注铁磁流体驱油, 实验及数值模拟

注水开发是保持地层压力、提高原油采收率的最 有效且应用最广的方法, 但由于长期注水冲刷形成的 注采井之间的“优势通道”以及油藏复杂地质因素使得 注人水并未能按照预期的驱替路径流动，导致波及范 围小、驱替效率低、原油动用程度低, 也是注水开发后 期油井高含水的一个重要影响因素 ${ }^{[1 ~ 3]}$. 如何发展新型 驱油技术, 进一步提高采收率已成为亟待解决的难题.

铁磁流体是由直径为纳米量级且具有磁响应能 力的铁磁性固体颗粒和作为载体的非磁性液体以及 分散剂三者混合而成的一种稳定的胶状液体 ${ }^{[4]}$. 作为 一种新型功能材料, 铁磁流体首先表现出一般流体 的特征, 它的运动遵循流体动力学规律; 其次它又是 磁性物质, 在磁场中受到磁场力作用, 因而它的行为 可以受到磁场的控制. 正因如此, 在实际中有着广泛
的应用, 比如磁流体密封、润滑、选矿、医疗器械、 声光调节等 ${ }^{[57]}$.

最近, 铁磁流体在石油工业上的应用研究受到 广泛关注，主要包括基于磁异常反演的储层裂缝识 别、油水前缘监测 ${ }^{[8 ~ 11]}$. 本文针对磁场作用下的铁磁 流体多孔介质流动物理过程，给出了流动数学方程 并建立了全隐式有限体积法数值离散格式, 最后采 用Newton-Raphson迭代方法求解，通过二维平面填 砂板流动实验对模型及算法的正确性进行了验证. 在此基础上，研究了利用磁场控制的铁磁流体驱油 问题，并与传统注水驱油效果进行了对比.

\section{1 铁磁流体的磁场力}

铁磁流体所表现出来的宏观磁化性能来源于其 
内部的磁性固相颗粒, 当不存在外磁场时, 由于热运 动的影响, 磁性颗粒的磁矩(即微小的磁场)取向杂乱 无章因而相互抵消; 当存在外磁场时, 磁矩按照外磁 场方向整齐排列, 从而铁磁流体在宏观上表现出磁 性, 如图1所示.

随着外磁场的增大, 铁磁流体的磁化强度增大 并达到最大值, 即饱和磁化强度. 本文中实验及数值 模拟采用的水基铁磁流体Hinano-FFW, 饱和磁化强 度 $M_{\max }=1.596 \times 10^{4} \mathrm{~A} / \mathrm{m}$, 其磁化曲线如图2所示, 并
通过一个反三角函数拟合，即

$$
M=\alpha \times \arctan (\beta \times H),
$$

其中, $\alpha=1 \times 10^{4}, \beta=3.5 \times 10^{-5}$, 此外对于任意磁场强度, 铁磁流体的磁化强度 $M$ 与其饱和度 $S_{\mathrm{ff}}$ 成线性关系:

$$
M\left(S_{\mathrm{ff}}\right)=M\left(S_{\mathrm{ff}}=1\right) S_{\mathrm{ff}} .
$$

在本文中, 外磁场由方形钕铁硼磁铁提供, 磁铁 具体参数见表 1 , 其三维磁场强度 $\boldsymbol{H}=\left(H_{x}, H_{y}, H_{z}\right)$ 由 $\mathrm{McCaig}^{[12]}$ 推导的公式求得

$$
H_{d}=G_{d}(x, y, z)-G_{d}(x+L, y, z), d=x, y, z,
$$

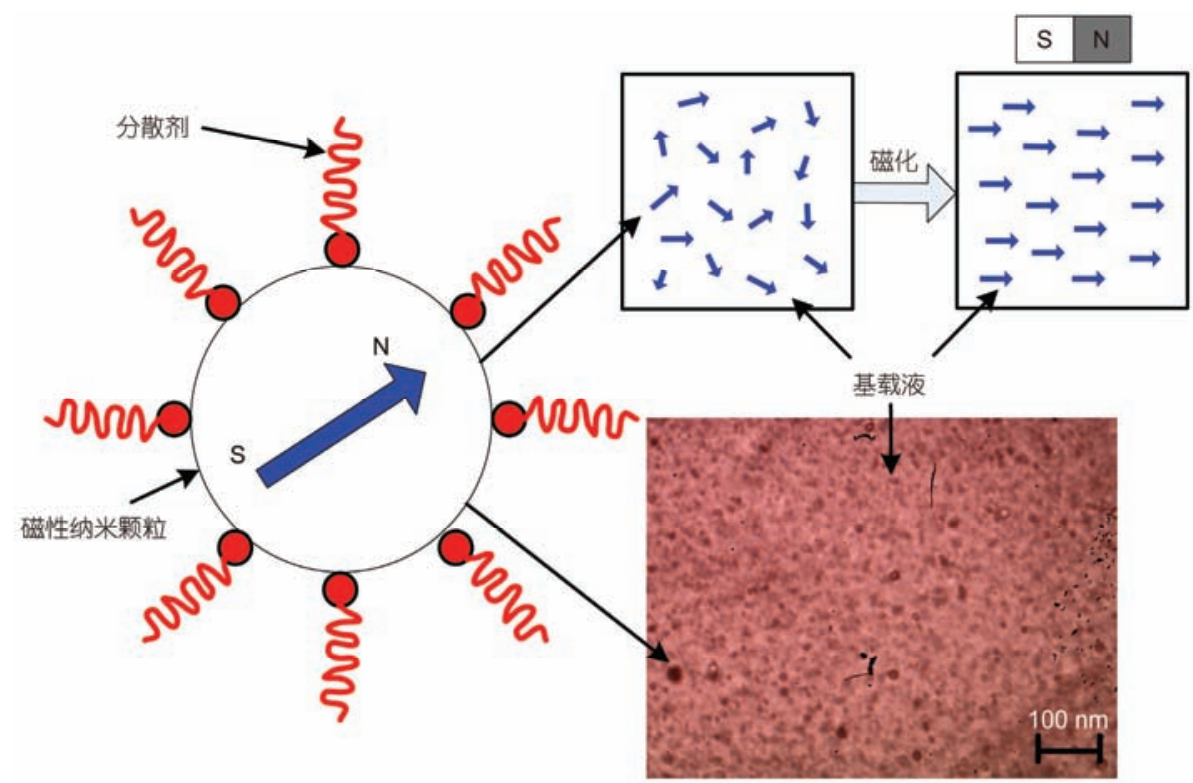

图 1 (网络版彩色)铁磁流体组成及磁化过程示意图

Figure 1 (Color online) The components and magnetization of ferrofluid

其中,

$$
\begin{gathered}
G_{x}(x, y, z)=\frac{B_{\mathrm{r}}}{4 \pi \mu_{0}}\left\{\arctan \left[\frac{(y+a)(z+b)}{x\left[(y+a)^{2}+(z+b)^{2}+x^{2}\right]^{1 / 2}}\right]+\arctan \left[\frac{(y-a)(z-b)}{x\left[(y-a)^{2}+(z-b)^{2}+x^{2}\right]^{1 / 2}}\right]\right. \\
\left.-\arctan \left[\frac{(y+a)(z-b)}{x\left[(y+a)^{2}+(z-b)^{2}+x^{2}\right]^{1 / 2}}\right]-\arctan \left[\frac{(y-a)(z+b)}{x\left[(y-a)^{2}+(z+b)^{2}+x^{2}\right]^{1 / 2}}\right]\right\}, \\
G_{y}(x, y, z)=\frac{B_{\mathrm{r}}}{4 \pi \mu_{0}} \ln \left\{\frac{(z+b)+\left[(z+b)^{2}+(y-a)^{2}+x^{2}\right]^{1 / 2}}{(z-b)+\left[(z-b)^{2}+(y-a)^{2}+x^{2}\right]^{1 / 2}} \times \frac{(z-b)+\left[(z-b)^{2}+(y+a)^{2}+x^{2}\right]^{1 / 2}}{(z+b)+\left[(z+b)^{2}+(y+a)^{2}+x^{2}\right]^{1 / 2}}\right\}, \\
G_{z}(x, y, z)=\frac{B_{\mathrm{r}}}{4 \pi \mu_{0}} \ln \left\{\frac{(y+a)+\left[(z-b)^{2}+(y+a)^{2}+x^{2}\right]^{1 / 2}}{(y-a)+\left[(z-b)^{2}+(y-a)^{2}+x^{2}\right]^{1 / 2}} \times \frac{(y-a)+\left[(z+b)^{2}+(y-a)^{2}+x^{2}\right]^{1 / 2}}{(y+a)+\left[(z+b)^{2}+(y+a)^{2}+x^{2}\right]^{1 / 2}}\right\} .
\end{gathered}
$$


其中, $B_{\mathrm{r}}$ 为磁铁剩余磁化强度, $2 a, 2 b, L$ 分别对应 3 个 方向长度, 如图3所示.

在外加磁场作用下, 铁磁流体内部磁性颗粒磁

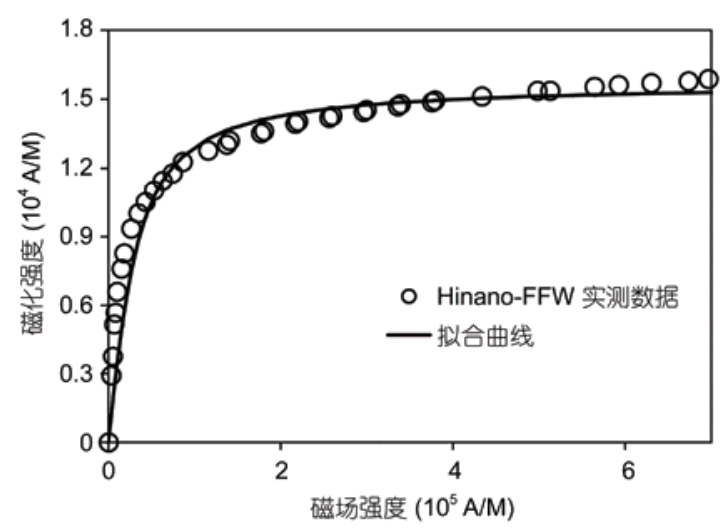

图 2 铁磁流体磁化强度随磁场强度变化曲线

Figure 2 Magnetization versus magnetic field strength for HinanoFFW

\section{表 1 实验及数值模拟所用磁铁的性质}

Table 1 The property of permanent magnet used for experiment and numerical simulation

\begin{tabular}{cll}
\hline 磁铁型号 & \multicolumn{1}{c}{ 参数符号 } & 参数值 \\
\hline \multirow{3}{*}{$\mathrm{PM} 1$} & 剩余磁化强度 $B_{\mathrm{r}}$ & $1.19 \mathrm{~T}$ \\
& 长度 $L$ & $0.127 \mathrm{~m}$ \\
& 宽度 $2 a$ & $0.0508 \mathrm{~m}$ \\
& 高度 $2 b$ & $0.0508 \mathrm{~m}$ \\
\hline \multirow{3}{*}{$\mathrm{PM} 2$} & 剩余磁化强度 $B_{\mathrm{r}}$ & $1.19 \mathrm{~T}$ \\
& 长度 $L$ & $0.0254 \mathrm{~m}$ \\
& 宽度 $2 a$ & $0.0191 \mathrm{~m}$ \\
& 高度 $2 b$ & $0.0191 \mathrm{~m}$ \\
\hline
\end{tabular}

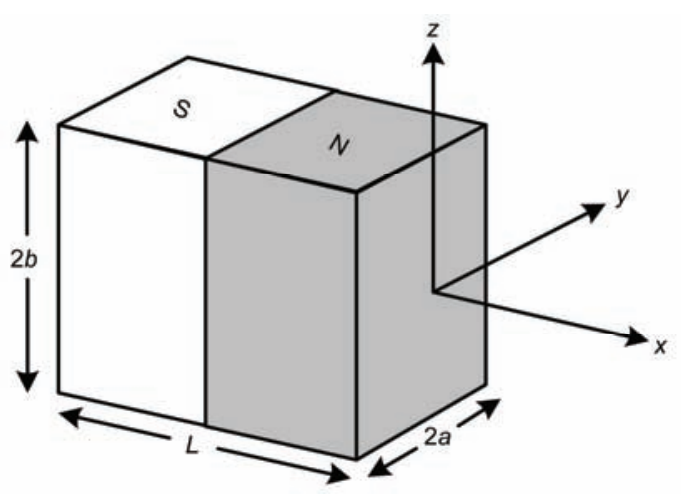

图 3 方形磁铁磁场坐标方向

Figure 3 Local coordinate system for the magnetic field produced by a permanent magnet
化后形成的次级磁场与外磁场相互作用，表现为铁 磁流体受到磁场力的作用, 磁场力的大小为 ${ }^{[13]}$

$$
\boldsymbol{F}_{\mathrm{m}}=\mu_{0} \boldsymbol{M} \cdot \nabla \boldsymbol{H},
$$

其中, $\mu_{0}=4 \pi \times 10^{-7} \mathrm{~T} \mathrm{~m} / \mathrm{A}$ 为真空磁导率, $\boldsymbol{M}$ 为磁化强 度, $\boldsymbol{H}$ 为磁场强度. 在铁磁流体中, 通常总能实现矢 量 $\boldsymbol{M}$ 和 $\boldsymbol{H}$ 相平行，于是 $\boldsymbol{F}_{\mathrm{m}}$ 可以写成

$$
\boldsymbol{F}_{\mathrm{m}}=\mu_{0} \frac{M}{H} \boldsymbol{H} \cdot \nabla \boldsymbol{H}=\mu_{0} \frac{M}{H}\left[\frac{1}{2} \nabla(\boldsymbol{H} \cdot \boldsymbol{H})-\boldsymbol{H} \times(\nabla \times \boldsymbol{H})\right],
$$

因为在铁磁流体中不存在传导电流, 因此 $\nabla \times \boldsymbol{H}=0$, 即

$$
\boldsymbol{F}_{\mathrm{m}}=\mu_{0} M \nabla H .
$$

\section{2 磁场-渗流场耦合流动模拟}

\section{1 两相流动数学方程}

考虑不可压缩油-铁磁流体两相渗流问题, 数学 方程如下.

(1) 质量守恒方程

由质量守恒定律可知在控制体积 $V$ 中的某一相 流体应满足

$$
\int_{\partial V}-\left(\rho_{\beta} \boldsymbol{v}_{\beta}\right) \cdot \boldsymbol{n} \mathrm{d} A+\int_{V} q_{\mathrm{m} \beta} \mathrm{d} V=\int_{V} \frac{\partial}{\partial t}\left(\rho_{\beta} \phi S_{\beta}\right) \mathrm{d} V,
$$

其中, $\rho_{\beta}$ 为 $\beta$-相流体密度; $v_{\beta}$ 为 $\beta$-相流体的渗流速度; $\boldsymbol{n}$ 为面 $\partial V$ 的单位外法向向量; $q_{\mathrm{m} \beta}$ 为源汇项; $\phi$ 为多孔 介质孔隙度; $S_{\beta}$ 为 $\beta$-相流体饱和度.

(2) 运动方程

由Darcy定律可知，流体的渗流速度 $\boldsymbol{v}_{\beta}$ 满足

$$
\boldsymbol{v}_{\beta}=-\frac{k_{\mathrm{r} \beta}}{\mu_{\beta}} \boldsymbol{k} \cdot\left(\nabla p_{\beta}-\rho_{\beta} g \nabla D\right),
$$

式中, $\boldsymbol{k}$ 为多孔介质的渗透率张量; $k_{\mathrm{r} \beta}$ 为 $\beta$-相流体的 相对渗透率; $\mu_{\beta}$ 为 $\beta$-相流体黏度; $p_{\beta}$ 为 $\beta$-相流体压力; $D$ 为深度; $g$ 为重力加速度常数. 特别地, 对于铁磁流 体，外磁场对其整体的作用，将表现为彻体力的形 式, 因此在均匀相铁磁流体的运动方程中将出现额 外的磁力项, 如(9)式所示, 铁磁流体运动方程为

$$
\boldsymbol{v}_{\mathrm{ff}}=-\frac{k_{\mathrm{rff}}}{\mu_{\mathrm{ff}}} \boldsymbol{k} \cdot\left(\nabla p_{\mathrm{ff}}-\rho_{\mathrm{ff}} g \nabla D-\mu_{0} M \nabla H\right),
$$

从式(2)和(12)可以看到, 铁磁流体的分布影响磁场 力的大小, 而外磁场通过磁场力的作用影响铁磁流 体的流动，因此，磁场作用下的铁磁流体多孔介质流 动过程本质上是一个磁场-渗流场耦合作用的过程. 


\section{2 有限体积离散格式}

用单元中心点值来表征整个单元物理量的平均 值, 因此式(10)可进一步写成

$$
\frac{\partial}{\partial t}\left(\rho_{\beta} \phi S_{\beta} V_{i}\right)=-\sum_{j \in \eta_{i}} \boldsymbol{n}_{i j} \cdot\left(\rho_{\beta} \boldsymbol{v}_{\beta}\right) A_{i j}+q_{\mathrm{m} \beta} V_{i},
$$

式中, $\eta_{i}$ 为控制体积单元 $i$ 的相邻单元 $j$ 的集合, $\boldsymbol{n}_{i j}$ 为单 元 $i$ 与相邻单元 $j$ 间的交界面单位外法线向量, $A_{i j}$ 为交 界面面积. 将运动方程代人式(13)可得

$$
\frac{\partial}{\partial t}\left(\rho_{\beta} \phi S_{\beta} V_{i}\right)=\sum_{j \in \eta_{i}} \boldsymbol{n}_{i j} \cdot\left(\rho_{\beta} \frac{k_{r \beta}}{\mu_{\beta}} \boldsymbol{k} \cdot \nabla \Phi_{\beta}\right) A_{i j}+q_{\mathrm{m} \beta} V_{i},
$$

式中, $\Phi_{\beta}=p_{\beta}-\rho_{\beta} g D$ 为 $\beta$-相流体的流动势, 特别 地, 对于铁磁流体来说, 由其运动方程(12)知其流动 势 $\Phi_{\mathrm{ff}}=p_{\mathrm{ff}}-\rho_{\mathrm{ff}} g D-\mu_{0} M H$.

对式(14)中时间项采用向后一阶差分, 空间上采 用中心差分格式，可得

$$
\begin{aligned}
& \frac{1}{\Delta t}\left[\left(\rho_{\beta} S_{\beta} \phi V\right)_{i}^{n+1}-\left(\rho_{\beta} S_{\beta} \phi V\right)_{i}^{n}\right] \\
= & \sum_{j \in \eta_{i}}\left(\rho_{\beta} \lambda_{\beta}\right)_{i j+1 / 2}^{n+1} \gamma_{i j}\left(\Phi_{\beta j}^{n+1}-\Phi_{\beta i}^{n+1}\right)+Q_{\beta i}^{n+1},
\end{aligned}
$$

式中,

$$
\left(\rho_{\beta}\right)_{i j+1 / 2}^{n+1}=\frac{\left[\left(\rho_{\beta}\right)_{i}^{n+1}+\left(\rho_{\beta}\right)_{j}^{n+1}\right]}{2}
$$

为单元交界面密度平均; $\gamma_{i j}=A_{i j} k_{i j+1 / 2} /\left(d_{i}+d_{j}\right)$ 为传 导率, $d_{i}$ 和 $d_{j}$ 分别为单元 $i$ 和单元 $j$ 中心到交界面的垂直 距离, $k_{i j+1 / 2}$ 为相邻单元 $i$ 和 $j$ 沿连接方向绝对渗透率 的调和平均值; 源汇项 $Q_{\beta i}^{n+1}=\left(q_{\mathrm{m} \beta}\right)_{i}^{n+1}=\rho_{\beta} q_{\beta i}^{n+1} V_{i}, q_{\beta}$ 定义为单位时间单位体积内流人控制体 $V$ 中的流体 体积; $\lambda_{\beta}=k_{r \beta} / \mu_{\beta}$ 为流度系数, 采用上游迎风加权

$$
\left(\rho_{\beta} \lambda_{\beta}\right)_{i j+1 / 2}^{n+1}= \begin{cases}\left(\rho_{\beta} \lambda_{\beta}\right)_{i}^{n+1}, & \text { if }\left(\Phi_{\beta j}^{n+1}-\Phi_{\beta i}^{n+1}\right) \leq 0, \\ \left(\rho_{\beta} \lambda_{\beta}\right)_{j}^{n+1}, & \text { if }\left(\Phi_{\beta j}^{n+1}-\Phi_{\beta i}^{n+1}\right)>0 .\end{cases}
$$

\section{3 数值离散方程求解}

采用Newton-Raphson迭代方法对本文中的数值 离散方程进行求解. 将数值离散方程(15)写成如下残 差形式:

$$
\begin{aligned}
R_{\beta i}^{n+1}= & \frac{1}{\Delta t}\left[\left(\rho_{\beta} S_{\beta} \phi V\right)_{i}^{n+1}-\left(\rho_{\beta} S_{\beta} \phi V\right)_{i}^{n}\right] \\
& -\sum_{j \in \eta_{i}}\left(\rho_{\beta} \lambda_{\beta}\right)_{i j+1 / 2}^{n+1} \gamma_{i j}\left(\Phi_{\beta j}^{n+1}-\Phi_{\beta i}^{n+1}\right)-\rho_{\beta} q_{\beta i}^{n+1} V_{i} .
\end{aligned}
$$

利用泰勒级数法对上式展开可得

$$
\sum_{l} \frac{\partial R_{\beta i}^{n+1}\left(\boldsymbol{x}^{p}\right)}{\partial x_{l}^{p}}\left(\delta x_{l}^{p+1}\right)=-R_{\beta i}^{n+1}\left(\boldsymbol{x}^{p}\right),
$$

其中, $x_{l}^{p}$ 表示在第 $p$ 个迭代步的第 $l$ 个主变量; $\delta x_{l}^{p+1}=x_{l}^{p+1}-x_{l}^{p}$ 为主变量在第 $p+1$ 个迭代步中的增 量. 显然上式中右端项及左端导数矩阵通过上一迭 代步求解结果可直接求取, 因此可求得下一步迭代 值 $x_{l}^{p+1}$ 并使得残差 $R\left(x_{l}^{p+1}\right)$ 进一步趋于零. 重复上述 迭代过程, 直至残差小于误差允许值 $\varepsilon$, 即 $\left|R\left(x_{l}^{p+1}\right)\right|<\varepsilon$, 本文中取 $\varepsilon=1 \times 10^{-5}$. 求解过程如图 4 所示.

\section{3 模型与算法验证}

本节中给出了一个简单算例, 通过与实验结果 的对比验证方法和程序的正确性. 考虑如图 5(a)所示 的平板模型, 模型尺寸 $12 \mathrm{~cm} \times 10 \mathrm{~cm} \times 0.2 \mathrm{~cm}$, 可视为 平面流动. 模型采用玻璃砂 $\mathrm{S} 1$ (颗粒目数 60 , 直径 $0.27 \mathrm{~mm}$ ) 结合环氧树脂胶结压实而成, 然后由有机 玻璃封装, 可视为均质各向同性, 经测量其孔隙度 $\phi=0.38$, 渗透率 $k=13.77 \times 10^{-12} \mathrm{~m}^{2}$.

实验模型水平放置并初始时刻饱和油，然后在 左端注人一小部分体积的铁磁流体Hinano-FFW(1.0 $\mathrm{mL}$ ), 其饱和磁化强度 $M_{\max }=1.596 \times 10^{4} \mathrm{~A} / \mathrm{m}$, 磁化曲 线如图2所示. 在右端放置磁铁PM1, 图 5(b)所示为 磁场强度分布。通过实验室测量得到油的黏度 $\mu_{0}=22.1 \mathrm{mPa} \mathrm{s}$, 铁磁流体的黏度 $\mu_{\mathrm{ff}}=5.8 \mathrm{mPa} \mathrm{s}$, 油的

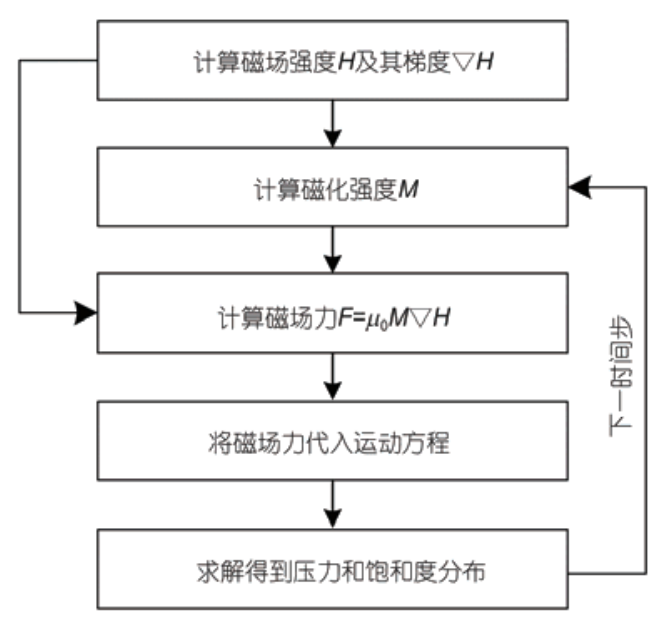

图 4 铁磁流体流动计算流程示意图

Figure 4 Schematic of ferrofluid flow calculation 

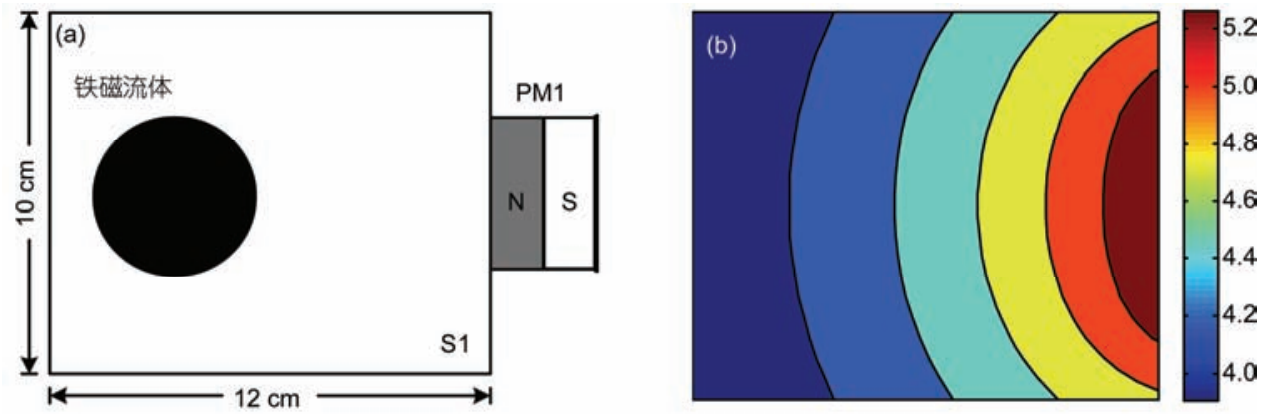

图 5 (网络版彩色)物理模型示意图及磁场强度分布. (a) 填砂平板流动实验模型; (b) 磁场强度 $\log _{10}(H)$ 分布

Figure 5 (Color online) The schematic of physical model and distribution of magnetic field strength. (a) Sand-filling plate model for flow experimental; (b) distribution of magnetic field strength $\log _{10}(H)$

密度 $\rho_{\mathrm{o}}=850 \mathrm{~kg} / \mathrm{m}^{3}$, 铁磁流体的密度 $\rho_{\mathrm{ff}}=1187 \mathrm{~kg} / \mathrm{m}^{3}$. 假设模型中残余油饱和度及束缚铁磁流体饱和度均 为 0 , 铁磁流体相相对渗透率 $k_{\mathrm{rff}}=S_{\mathrm{ff}}^{2}$, 油相相对渗透 率 $k_{\mathrm{ro}}=\left(1-S_{\mathrm{ff}}\right)^{2}$.

应用本文方法对上述物理实验过程进行数值模 拟, 计算中流体忽略毛管力和重力的影响. 如图6所 示, 在磁场力的作用下, 铁磁流体逐渐向右端磁铁位 置流动, 对比 $0,20,50 \mathrm{~min}$ 时刻实验及数值模拟的铁 磁流体分布，可以看到两者流动过程基本一致.

利用二值化图像方法对图6(a)中50 min时刻的实
验结果进行处理，得到铁磁流体的像素分布，通过对 某点附近区域内像素统计可以近似得到该点饱和度, 其中选取的区域大小与数值模拟网格大小相等 $(0.25$ $\mathrm{cm} \times 0.25 \mathrm{~cm}$ ). 图7(b) 所示为实验及数值模拟得到沿 平板模型中轴线饱和度分布对比, 两者吻合较好.

通过以上实验结果及数值计算结果的对比, 验 证了本文数学模型和算法的正确性. 值得注意的是, 由于物理模型制作过程中并不能保证玻璃砂填充的 完全均匀, 因此实验中铁磁流体的流动形态、饱和度 分布与计算结果存在小的误差，但基本一致.
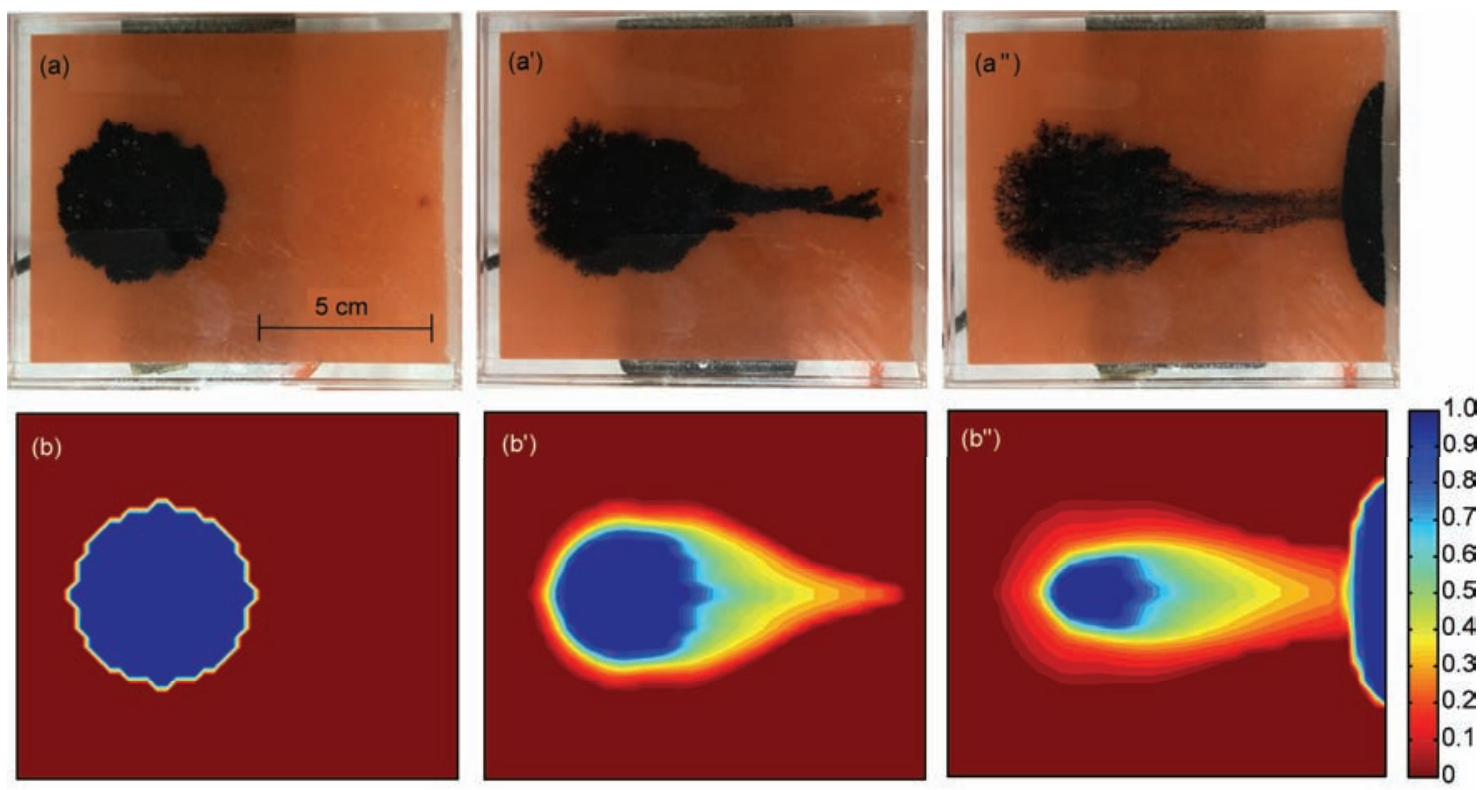

图 6 (网络版彩色)平板模型流动实验及数值模拟铁磁流体不同时刻饱和度分布对比. (a) ( $\left.a^{\prime \prime}\right)$ 分别为 $0,20,50$ min时刻物理实验结果; (b) ( $\left.b^{\prime \prime}\right)$ 分别为 $0,20,50 \mathrm{~min}$ 时刻数值计算结果

Figure 6 (Color online) The ferrofluid saturation distribution of flow experiment and numerical simulation at different time. (a)-(a") respectively show the experimental results at $0,20,50 \mathrm{~min} ;(b)-\left(b^{\prime \prime}\right)$ respectively show the calculational results at $0,20,50 \mathrm{~min}$ 

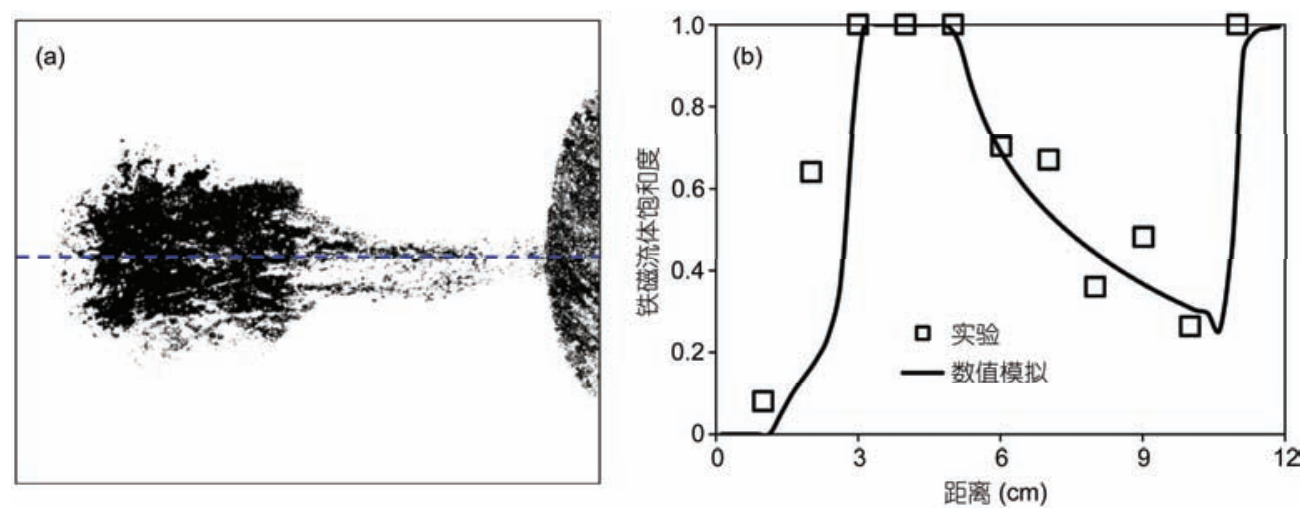

图 7 (网络版彩色) $50 \mathrm{~min}$ 时刻铁磁流体分布及沿平板模型中轴线饱和度对比. (a) 铁磁流体二值化分布; (b) 实验及数值模拟铁磁流体饱和度 对比

Figure 7 (Color online) The ferrofluid distribution and the saturation comparison between experimental and calculational result along the plate model's central axis at 50 min. (a) Ferrofluid distribution based on image binarization; (b) ferrofluid saturation along the plate model's central axis of experiment and numerical simulation

\section{4 非均质模型驱油数值模拟}

如图6所示，由于外磁场存在，铁磁流体受到磁 场力的作用，并向磁场强度高的地方流动，即铁磁流 体的流动行为可以由施加的外磁场控制, 因此利用 铁磁流体驱油具有控制驱替路径从而提高驱替波及 范围的优势. 本节分别考虑平面及纵向非均质油藏 模型，对比注水及注铁磁流体驱油效果.

\section{1 平面非均质模型}

考虑如图 8(a)所示的一注一采平面非均质模型, 模型尺寸为 $5 \mathrm{~cm} \times 5 \mathrm{~cm}(x \times y)$, 注人采出速度均为 $q=0.01 V_{\mathrm{P}} / \mathrm{min}, V_{\mathrm{P}}$ 为总孔隙体积; 模型中间为粗砂 $\mathrm{S} 1$ (颗粒目数 60 , 直径 $0.27 \mathrm{~mm}$ ) 填充, 两边为细砂 $\mathrm{S} 2$ (颗粒目数 80 , 直径 $0.177 \mathrm{~mm}$ ) 填充, 其孔隙度分别为 $\phi_{1}=0.38, \phi_{2}=0.27$, 渗透率为 $k_{1}=13.77 \times 10^{-12} \mathrm{~m}^{2}, k_{2}=$ $1.38 \times 10^{-12} \mathrm{~m}^{2}$. 在模型左上角及右下角各放置磁铁 PM2, 磁场强度如图7(b)所示.

模型初始时刻饱和油，残余油饱和度及束缚水或 束缚铁磁流体饱和度均为零. 对该平面非均质模型分 别采用水及铁磁流体进行驱替并对比驱油效果, 其中 油的黏度 $\mu_{0}=22.1 \mathrm{mPa} \mathrm{s}$, 铁磁流体的黏度 $\mu_{\mathrm{ff}}=5.8 \mathrm{mPa}$ $\mathrm{s}$, 水的黏度 $\mu_{\mathrm{w}}=1.0 \mathrm{mPa} \mathrm{s}$, 油的密度 $\rho_{\mathrm{o}}=850 \mathrm{~kg} / \mathrm{m}^{3}$, 铁
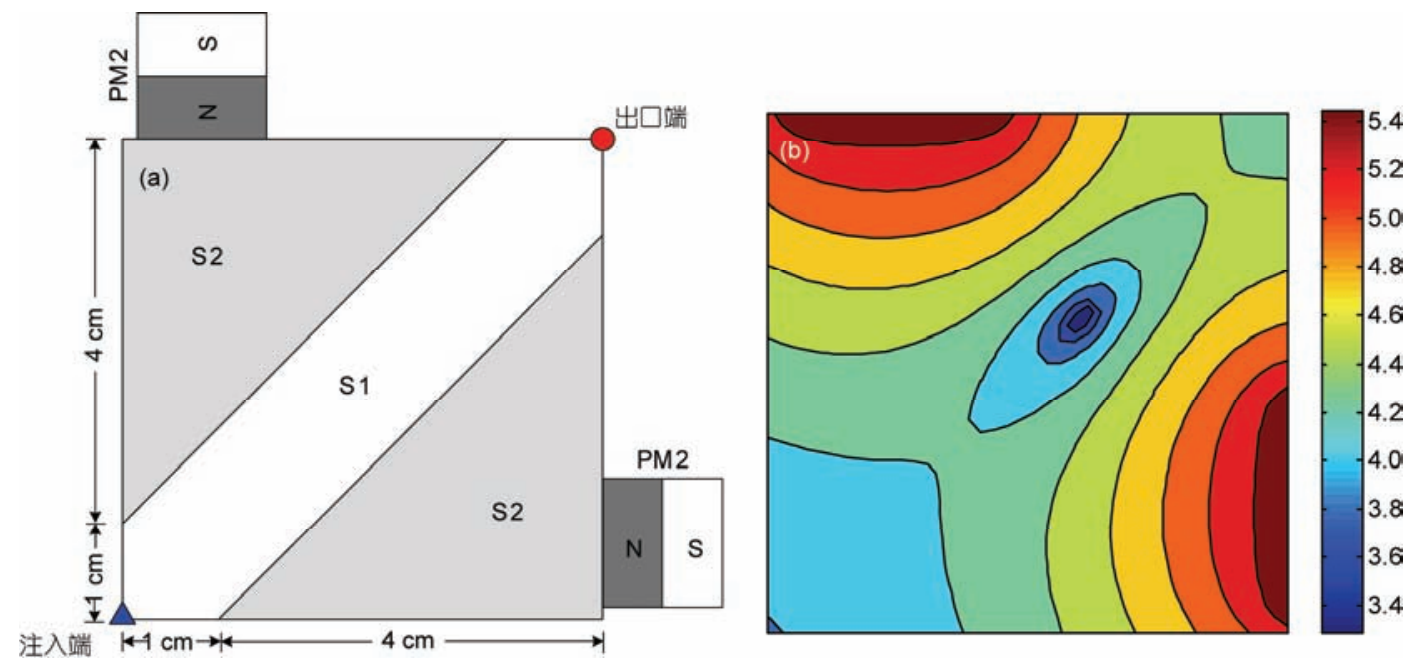

图 8 (网络版彩色)物理模型示意图及磁场强度分布. (a) 平面非均质注采模型; (b) 磁场强度 $\log _{10}(H)$ 分布

Figure 8 (Color online) The schematic of physical model and distribution of magnetic field strength. (a) Horizontal heterogeneous injectionproduction model; (b) distribution of magnetic field strength $\log _{10}(H)$ 
磁流体的密度 $\rho_{\mathrm{ff}}=1187 \mathrm{~kg} / \mathrm{m}^{3}$, 水的密度 $\rho_{\mathrm{w}}=1000$ $\mathrm{kg} / \mathrm{m}^{3}$. 驱替相 (水或铁磁流体) 相对渗透率 $k_{\mathrm{r} \alpha}=$ $S_{\alpha}^{2}(\alpha=\mathrm{w}$ or ff $)$, 油相相对渗透率 $k_{\mathrm{ro}}=\left(1-S_{\alpha}\right)^{2}$.

对于水驱过程, 由于油水黏度差别较大, 并且模 型中间存在高渗带, 注人水基本沿中间高渗带流动, 从而导致其波及范围小、动用程度低, 因而出口端见 水时间早. 对于注铁磁流体驱油过程, 在驱替前期注 人的铁磁流体主要沿中间高渗带流动, 随着铁磁流 体流动到磁源附近, 磁场力逐渐增大, 铁磁流体在磁 场力的作用下驱向模型两边相对低渗区域, 对比于 水驱驱替波及范围明显增大, 因此动用程度高、出口 端见水时间较晚, 如图9所示.

定义出口端含水/含铁磁流体率

$$
f_{\alpha}=\frac{q_{\alpha}}{q_{\alpha}+q_{\mathrm{o}}},
$$

其中, $\alpha=\mathrm{w}$ or ff 为驱替相(水或铁磁流体), $\mathrm{o}$ 为被驱 替相油; $q_{\alpha}, q_{\mathrm{o}}$ 分别为出口端所采出的驱替相及被驱 替相的体积量. 如图10所示, 对比注水驱油及注磁流 体驱油开发效果可以看到: 首先, 水驱过程无水产油
时间较短，仅占整个驱油过程 $10 \% ，$ 而注铁磁流体驱 油可延长至 $22 \%$; 其次, 在注人 1.5 倍孔隙体积驱替 液后前者含水率高达 $95 \%$, 而后者仅 $83 \%$, 因此对于 后者来说还具有较好的开发潜力; 再次, 由于注人的 铁磁流体在磁场力作用下流向模型两边相对低渗透 区域, 提高了驱替波及范围、动用程度, 采出程度达 到 74\%, 而水驱过程中由于注人水基本沿中间高渗 带流向出口端, 因此驱替波及范围小, 采出程度仅 $39 \%$.

\section{2 纵向非均质模型}

考虑如图11(a)所示的纵向非均质油藏模型, 模 型尺寸同样为 $5 \mathrm{~cm} \times 5 \mathrm{~cm}(x \times z)$, 重力方向垂直向下. 其中注人采出井位于模型两端并贯穿整个模型, 注 人采出速度均为 $q=0.01 V_{\mathrm{P}} / \mathrm{min}$; 模型上半部分为粗玻 璃砂 $\mathrm{S} 1$, 下半部分为细玻璃砂 $\mathrm{S} 2$. 在模型底部放置2 个磁铁PM2, 磁场强度如图11(b)所示. 对该纵向非 均质模型分别采用水及铁磁流体进行驱替, 对比驱 油效果.
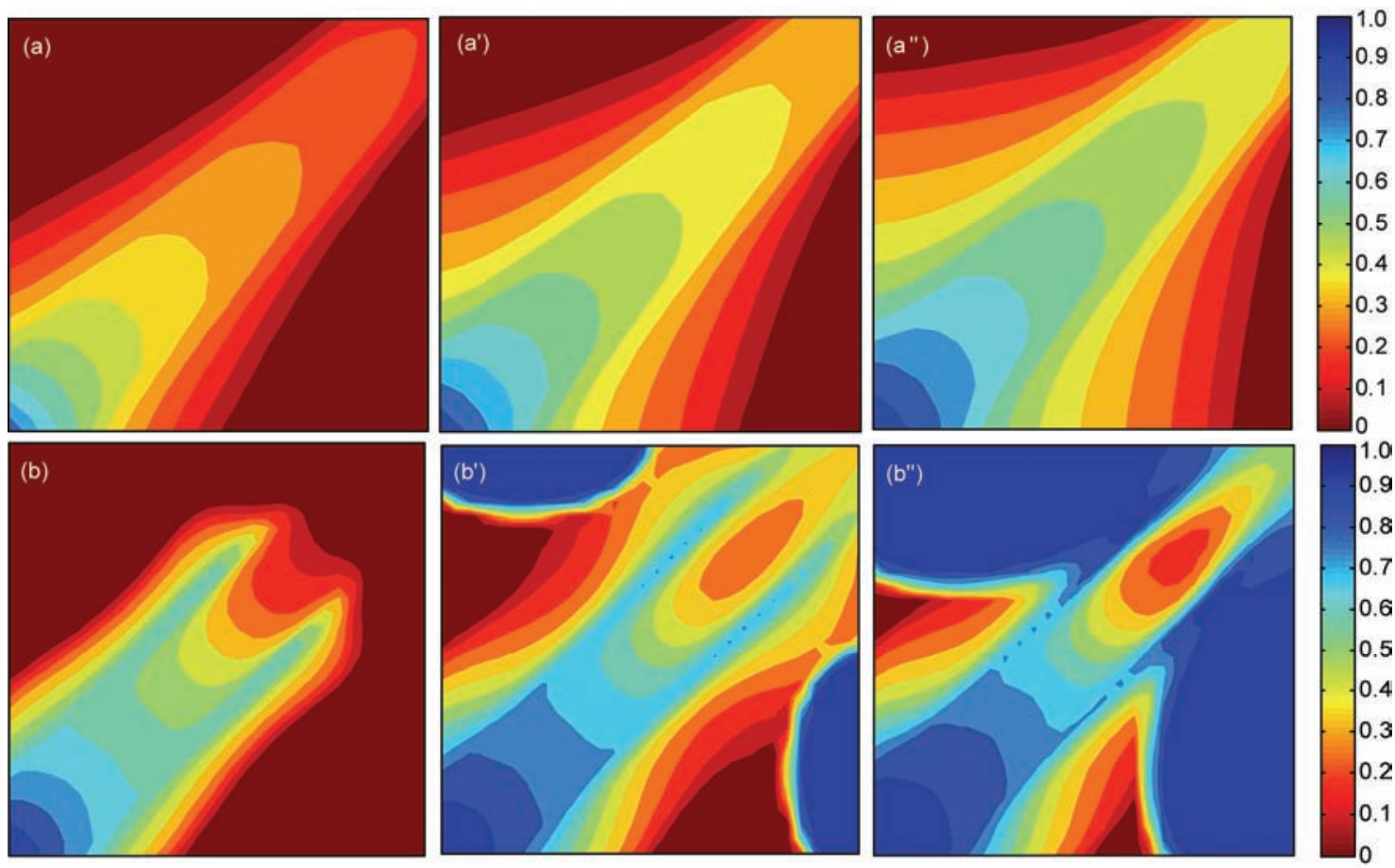

图 9 (网络版彩色)水平非均质模型注水及注铁磁流体驱油不同注人体积时饱和度分布. (a) (a")分别为水注人量为 0.25 倍, 0.75 倍, 1.5 倍孔隙 体积时水饱和度分布; (b) (b") 分别为铁磁流体注人量为 0.25 倍, 0.75 倍, 1.5 倍孔隙体积时铁磁流体饱和度分布

Figure 9 (Color online) The saturation distribution at different injection volume during water-flooding and ferrofluid-flooding process on the horizontal heterogeneous injection-production model. (a)-(a") respectively show the water saturation distribution at $0.25 V_{\mathrm{P}}, 0.75 V_{\mathrm{P}}, 1.5 V_{\mathrm{P}}$ injection volume during the water flooding process; $(\mathrm{b})-\left(\mathrm{b}^{\prime \prime}\right)$ respectively show the ferrofluid saturation distribution at $0.25 V_{\mathrm{P}}, 0.75 V_{\mathrm{P}}, 1.5 V_{\mathrm{P}}$ injection volume during the ferrofluid flooding process 

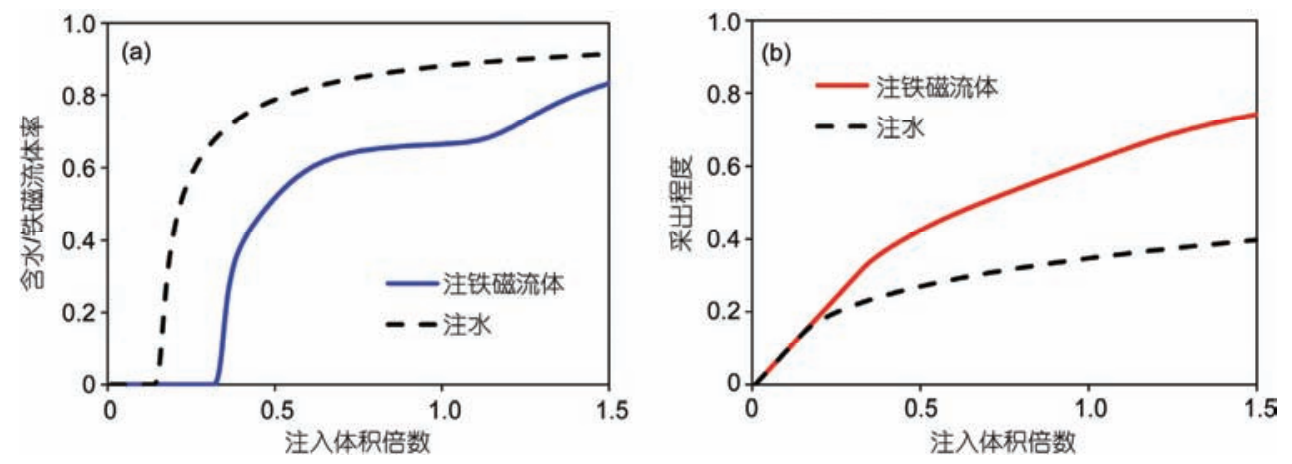

图 10 (网络版彩色)注水及注铁磁流体驱油过程中生产指示曲线. (a) 含水/铁磁流体曲线; (b) 采收率曲线

Figure 10 (Color online) The production index curves of water-flooding and ferrofluid-flooding. (a) Water cut and ferrofluid cut curves; (b) recovery curves of water-flooding and ferrofluid-flooding
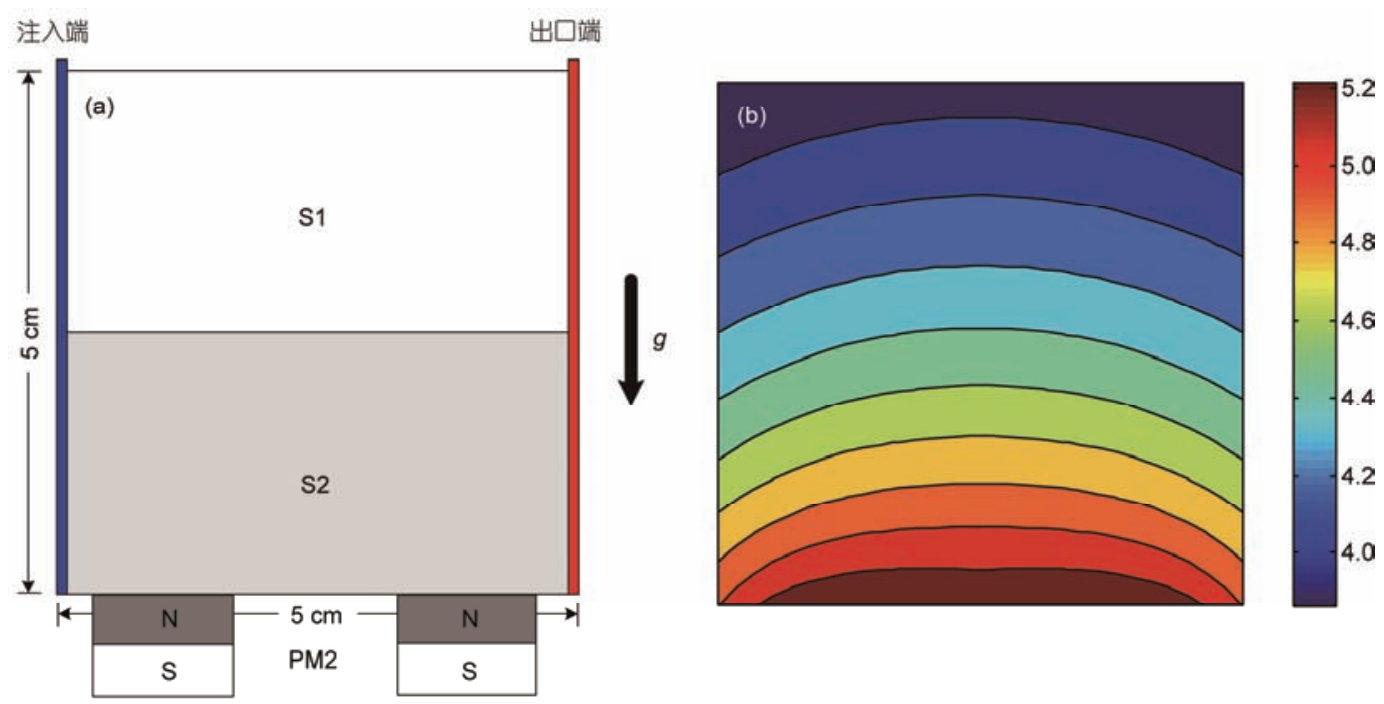

图 11 (网络版彩色)物理模型示意图及磁场强度分布. (a) 纵向非均质注采模型; (b) 磁场强度 $\log _{10}(H)$ 分布

Figure 11 (Color online) The schematic of physical model and distribution of magnetic field strength. (a) Vertical heterogeneous injection-production model; (b) distribution of magnetic field strength $\log _{10}(H)$

同样，对于水驱过程，由于油水黏度差及高渗带 的影响, 注人水沿上半部分流动速度快、生产井上半 段首先见水; 此外, 由于重力的作用, 模型下半部分 注人水主要沿底部流动, 从而导致模型中部存在大 量剩余油，如图12(a)所示. 对于注铁磁流体驱油过 程, 由于模型底部磁铁的存在, 注人的铁磁流体在磁 场力作用下向模型下半部分较难驱替的低渗带流动, 相对于水驱驱替波及范围明显增大, 因此动用程度 高, 如图12(b)所示.

对比注水驱油及注磁流体驱油开发效果可以看 到: 首先, 水驱过程无水产油时间较短, 仅占整个驱 油过程 $12 \%$, 注铁磁流体驱油为 19\%; 其次, 由于注 人的铁磁流体在磁场力作用下流向模型下半部分低
渗透区域，提高了驱替波及范围、动用程度，采出程 度达到 $76 \%$, 而水驱过程中由于模型中部存在部分 原油未被动用、水驱驱替波及范围小, 采出程度仅 $55 \%$, 如图13所示.

从数值算例的计算结果可以看到：由于多孔介 质非均质性的影响, 水驱过程中存在较难波及的区 域, 从而导致波及范围小、原油的动用程度低; 而对 于铁磁流体驱, 存在的外加磁场使得铁磁流体受到 磁场力的作用，通过布置外加磁场可以改变磁场力 的大小及方向, 进而改变驱替方向, 从而控制铁磁流 体朝低波及区域驱替, 此外, 由于受到的磁场力作为 一种额外驱替力, 更有利于铁磁流体进人低波及区 域从而置换原油. 因此, 相对于传统水驱, 外磁场控 

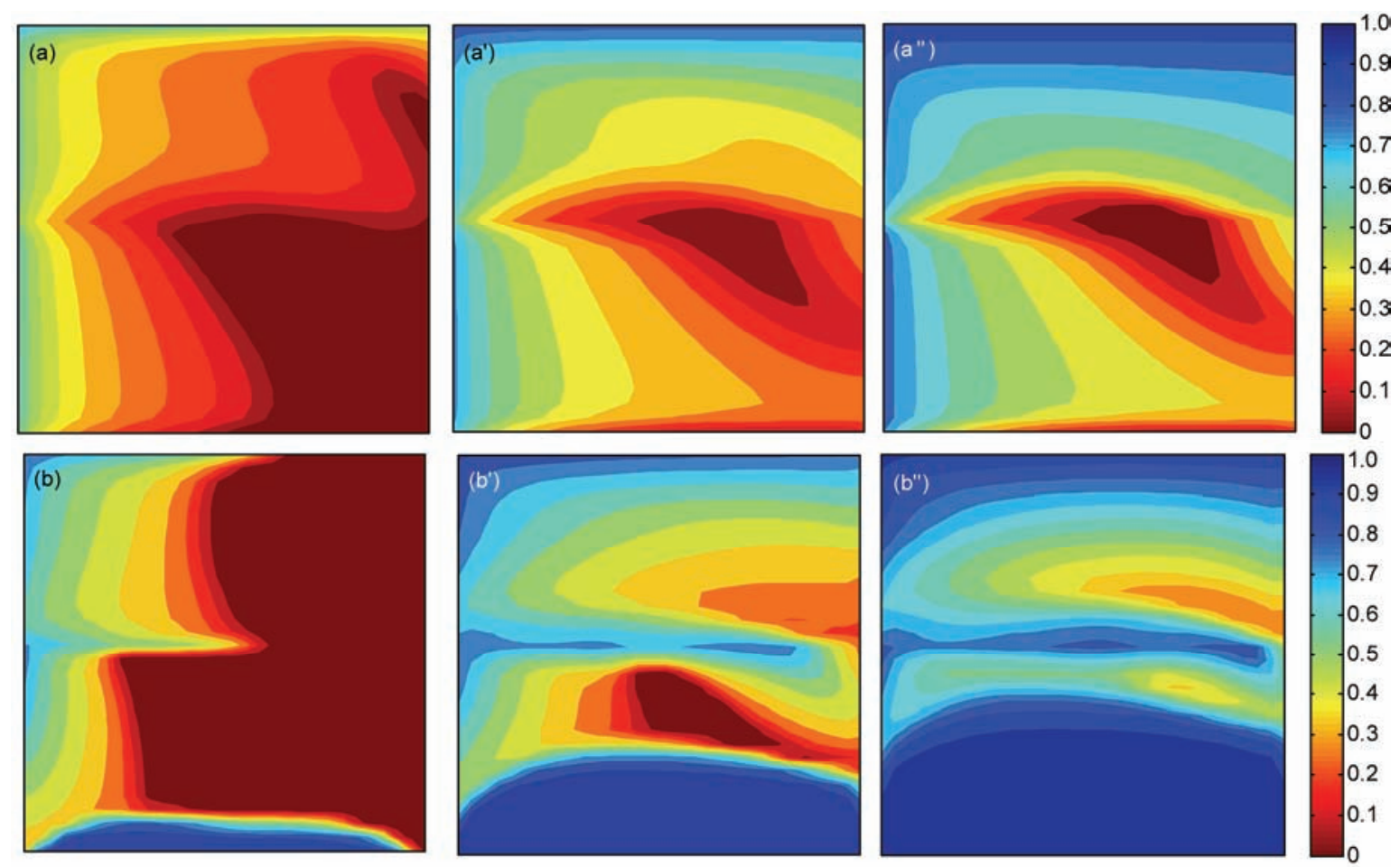

图 12 (网络版彩色)纵向非均质模型注水及注铁磁流体驱油不同注人体积时饱和度分布. (a) (a")分别为水注人量为 0.25 倍, 0.75 倍, 1.5 倍孔隙 体积时水饱和度分布; (b) (b")分别为铁磁流体注人量为 0.25 倍, 0.75 倍, 1.5 倍孔隙体积时铁磁流体饱和度分布

Figure 12 (Color online) The saturation distribution at different injection volume during water-flooding and ferrofluid-flooding process on the vertical heterogeneous injection-production model. (a)-(a") respectively show the water saturation distribution at $0.25 V_{\mathrm{P}}, 0.75 V_{\mathrm{P}}, 1.5 V_{\mathrm{P}}$ injection volume during the water flooding process; (b)-(b") respectively show the ferrofluid saturation distribution at $0.25 V_{\mathrm{P}}, 0.75 V_{\mathrm{P}}, 1.5 V_{\mathrm{P}}$ injection volume during the ferrofluid flooding process
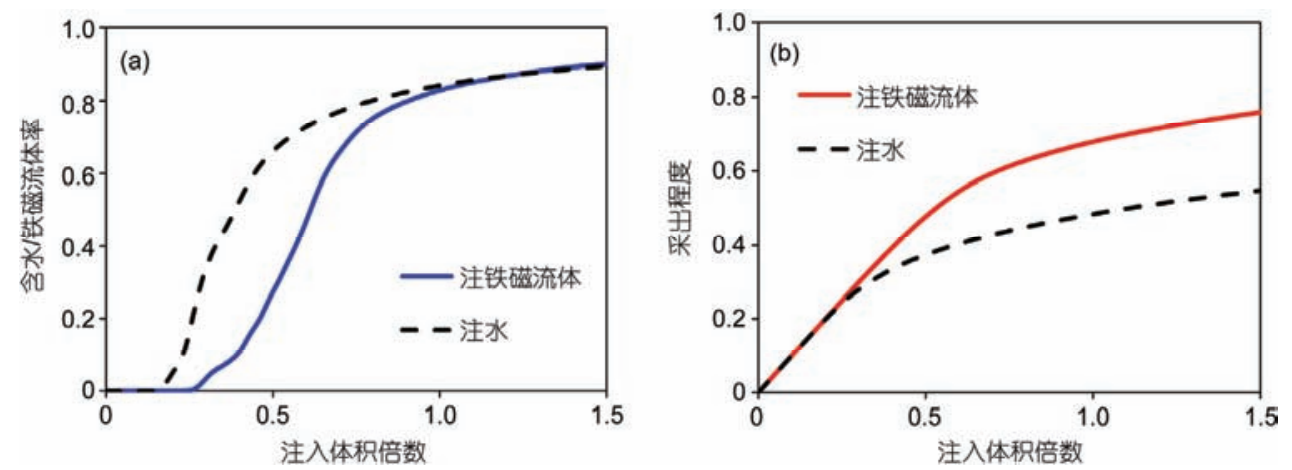

图 13 (网络版彩色)注水及注铁磁流体驱油过程中生产指示曲线. (a) 含水/铁磁流体曲线; (b) 采收率曲线

Figure 13 (Color online) The production index curves of water-flooding and ferrofluid-flooding. (a) Water cut and ferrofluid cut curves; (b) recovery curves of water-flooding and ferrofluid-flooding

制下的铁磁流体驱油技术能够提高驱替波及范围, 从而提高原油采收率.

本文研究了实验室尺度下的铁磁流体驱油问题, 其磁场通过布置于模型附近的磁铁提供, 针对现场 注铁磁流体驱油问题, 吴永涁等人 ${ }^{[14]}$ 提出了一套铁 磁流体驱替开采油藏的思想和方法: 外加磁场由放
置于井下的电磁发生器提供, 通过调节磁场大小改 变油层中铁磁流体的驱油方向和速度, 有效动用注 采井间原油、提高注人介质波及效率. 此外, 本文针 对的是宏观尺度下的铁磁流体驱油问题, 其本质上 还是物理法驱油提高采收率, 是否在微观孔隙尺度 上有更大的影响, 以及界面张力等效应还需要从孔 
隙尺度上更细致的研究，也是下一步的研究方向.

\section{5 结论}

通过实验和理论计算表明: 铁磁流体驱油是一 种具有较大潜力的提高采收率的方法.

(1) 外磁场作用下的注铁磁流体驱油过程本质 上是一个考虑磁场-渗流场耦合的多孔介质两相流动 问题, 本文首先给出了相应流动数学模型, 并推导了 全隐式有限体积数值计算格式, 通过二维填砂平板 流动实验验证了模型和算法的正确性.
(2) 通过数值模拟研究了平面及纵向非均质多 孔介质中注铁磁流体驱油问题, 并对比了注水驱油 开发效果，可以看到在相同注人体积情况下注铁磁 流体驱油相对于注水驱油较大幅度提高了采收率, 显示出较大的提高采收率潜力.

(3) 从计算结果可以看出, 外磁场对铁磁流体的 作用表现为磁彻体力形式并牵引其向磁场强度高的 区域流动. 因此，当存在高导流通道，例如高渗带 时，通过布置外磁场可以使得磁场力起到 “分流”作 用，从而提高驱替波及范围继而提高采出程度.

\section{参考文献}

1 Han D K. Precisely predicting abundant remaining oil and improving the secondary recovery of mature oilfields (in Chinese). Acta Petrol Sin, 2007, 28: 73-78 [韩大匡. 准确预测剩余油相对富集区提高油田注水采收率研究. 石油学报, 2007, 28: 73-78]

2 Li Y. Study on enhancing oil recovery of continental reservoir by water drive technology (in Chinese). Acta Petrol Sin, 2009, 30: 396-399 [李阳. 陆相高含水油藏提高水驱采收率实践. 石油学报, 2009, 30: 396-399]

3 Yu Q T. Oil field development three major rich areas of "large scale" unswept remaining oil in water flooded bedded sanstone reservoirs (in Chinese). Acta Petrol Sin, 2000, 21: 45-50 [俞启泰. 注水油藏大尺度未波及剩余油的三大富集区. 石油学报, 2000, 21: 45-50]

4 Rosensweig R E. Magnetic fluids. Sci Am, 1982, 247: 136-145

5 Raj K, Moskowitz R. Commercial applications of ferrofluids. J Magn Magn Mater, 1990, 85: 233-245

6 Scherer C, Figueiredo Neto A M. Ferrofluids: Properties and applications. Braz J Phys, 2005, 35: 718-727

7 Liu H D, Xu W, Wang S G, et al. Hydrodynamic modeling of ferrofluid flow in magnetic targeting drug delivery. Appl Math Mech, 2008, 29: 1341-1349

8 Sengupta S. An innovative approach to image fracture dimensions by injecting ferrofluids. In: Proceedings of the Abu Dhabi International Petroleum Conference and Exhibition. Texas: Society of Petroleum Engineers, 2012

9 Ko S, Prigiobbe V, Huh C. Accelerated oil droplet separation from produced water using magnetic nanoparticles. In: Proceedings of the SPE Annual Technical Conference and Exhibition. Texas: Society of Petroleum Engineers, 2014

10 Rahmani A R, Bryant S L, Huh C, et al. Crosswell magnetic sensing of superparamagnetic nanoparticles for subsurface applications. SPE J, 2015, 20: 1067-1082

11 Rahmani A R, Bryant S L, Huh C. Characterizing reservoir heterogeneities using magnetic nanoparticles. In: Proceedings of the SPE Reservoir Simulation Symposium. Texas: Society of Petroleum Engineers, 2015

12 MacCaig M, Clegg A G. Permanent Magnets in Theory and Practice. London: Pentech Press, 1987

13 Neuringer J L, Rosensweig R E. Ferrohydrodynamics. Phys Fluids, 1964, 7: 1927-1937

$14 \mathrm{Wu}$ Y B, Wang H Z. The method and well patterns for flooding oil reservior using nano magnetic fluid (in Chinese). PRC Patent, CN201310217165.X, 2013-10-2 [吴永彬, 王红庄. 纳米磁流体驱替开采油藏的方法及其井网结构. 中国专利, CN201310217165, 2013-10-2] 


\title{
Numerical simulation of ferrofluid flow in porous media under coupled magnetic and seepage fields
}

\author{
YAO Jun ${ }^{1 *}$, HUANG Tao ${ }^{1}$, HUANG ZhaoQin ${ }^{2 *}$, XIE HaoJun ${ }^{1}$, LIU JunRong ${ }^{1} \&$ ZHANG JianGuang ${ }^{1}$ \\ ${ }^{1}$ School of Petroleum Engineering, China University of Petroleum, Qingdao 266580, China; \\ ${ }^{2}$ Department of Petroleum Engineering, Colorado School of Mines, Golden CO 80401, USA \\ *Corresponding authors, E-mail: yaojun@upc.edu.cn; emc.group.upc@gmail.com
}

Water flooding is an efficient approach to maintain reservoir pressure and has been used widely to enhance oil recovery. However, preferential water pathways generated after long-term water flooding process and the strongly heterogeneous reservoirs can significantly decrease the sweep efficiency. Therefore, the utilization ratio of injected water is seriously affected. Most water-flooded reservoirs are in their late development stage, and their water cuts are more than 90\%. How to develop new flooding technology to further improve the oil recovery is a pressing problem.

Ferrofluids are colloidal suspensions of magnetic particles of diameter approximately $10 \mathrm{~nm}$ stabilized in various carrier liquids. In the presence of an external magnetic field, a ferrofluid becomes magnetized as the particles align with the magnetic field. In the presence of a gradient in the magnetic field strength, a magnetic body force is produced on the ferrofluid so that the attractive magnetic forces allow the ferrofluid to be manipulated to flow in any desired direction through control of the external magnetic field without any direct physical contact. In consideration of this properties, the potential of using the ferrofluid as a new kind of displacing fluid for flooding in oil reservoir is been studied in this paper at the first time. Considering the physical process that the mobilization of ferrofluid through porous media by application of strong external magnetic fields, we introduced the magnetic force into the Darcy equation to coupling the magnetic field and seepage flow field. The steps involved in calculating ferrofluid flow in porous media are (1) calculation of the external magnetic field strength produced by permanent magnet, (2) calculation of the magnetization using the magnetization curve of ferrofluid and initial ferrofluid saturation, (3) calculation of the magnetic force on the fluid, (4) addition of the magnetic force to the pressure gradient and gravitational body force terms, and (5) calculation of the liquid phase pressure and saturation, (6) update the magnetization based on the calculated ferrofluid saturation for the next step calculation. Using the fully implicit finite volume method to solve the mathematical model, and the validity and accuracy of the mathematical model and numerical algorithm are demonstrated through a experiment which ferrofluid flowing from left to right with an initial circular injection through oil-saturated sand in a 2-D horizontal cell.

At last, based on the above the numerical simulation method, the water-flooding and ferrofluid-flooding in horizontal and vertical heterogeneous porous media have been studied: because there is a relatively higher permeability zone between injection well and production well, most of the injected water flow along the higher permeability zone and small amount of oil have been displaced, the utilization ratio of injected water is low; however, the ferrofluid can be manipulated to flow in desired direction through control of the external magnetic field, so that using ferrofluid for flooding can raise the scope of the whole displacement, as a consequence, the oil recovery has been improved more than $20 \%$ compared to water flooding. Thus, through the experiments and theoretical calculations show that: the ferrofluid flooding is a large potential method for enhanced oil recovery.

ferrofluid, porous media, magnetic-seepage field coupling, ferrofluid flooding, experiment and numerical simulation

doi: 10.1360/N972015-01460 